\title{
From borders and landscape to ecosystem: reconfiguring library services to meet the needs of South African youth
}

\author{
Genevieve Hart ${ }^{1}$ and Mary Nassimbeni ${ }^{2}$ \\ ghart@uwc.ac.za; mary.nassimbeni@uct.ac.za
}

\begin{abstract}
Received: 06 March 2013
Accepted: 04 June 2013

In this article we consider the configuration of the South African library and information services (LIS) sector, and analyse the extent to which its structuring facilitates or hinders optimum service to the children and youth of South Africa. The background to our investigation is the crisis in public schooling and the plight of South African youth who suffer disproportionate rates of poverty and unemployment. In our investigation we examine the planning and practice in two new libraries - one a community library, and one a joint-use library for learners and local residents - in an effort to establish the extent to which libraries may partner with schools to take advantage of new thinking that recommends a whole system approach, encapsulated in the metaphor of LIS as an ecosystem. We conclude that this new approach might generate models of service delivery that transcend boundaries that traditionally delineate and confine sub-sectors in the LIS sector.
\end{abstract}

Keywords: South Africa, library as ecosystem, public libraries, school libraries, collaboration

\section{Introduction}

The ecological concept of "ecosystem" has been borrowed by many disciplines, including library and information science (for example Davenport \& Prusak 1997; Williamson 2005; Walter 2008). It serves as an image for the "bigger picture" strategic thinking that recognises that the good of the whole comes from the health of its parts and the relationships among them. In biology an ecosystem is characterised by complexity of relationships and dependencies among the diversity of the species inhabiting an area where change is felt throughout the system. Each subsystem might serve a specific range of species; but, if one subsystem fails to meet the needs of its dependents then it impacts on all the other systems and species falling under the larger system. However, the ecological concept of "adaptation" denotes the capacity of systems to change and to evolve to meet changing needs - under certain circumstances (Nardi \& O'Day 1999).

In his article on the future of academic libraries, Walter argues that the common geographical metaphors, such as "borders" and "landscape," should be replaced with ecological images such as "mutualism" and "co-evolution". He points out that "the library is home to multiple species, and its relations grow more and more complex" (2008). The metaphor of ecosystem is, according to Walter, "flexible"; it can be applied to interactions among library professionals and library sectors and also to those between libraries and library users.

South African library and information services (LIS) today still comprise the traditional sub-systems - national, academic, corporate, public/community, and school. In 2010, there were 7,384 libraries, made up of:

- 366 community libraries within the six metropolitan areas

- 1,386 community libraries affiliated to the nine provincial library services

- 210 higher education libraries

- 1,801 functional school libraries ${ }^{3}: 7.23 \%$ of all schools ${ }^{4}$

- 112 special and government departmental libraries

- Two National libraries (one in the conventional sense, and a national library for the blind) (South African Yearbook 2011/2012 2012).

Each of these categories has its own governance structures. And each is perceived to have its own niche user community; indeed, the standard definitions of the categories rely on these perceptions.

It is interesting to speculate how South African LIS might have evolved differently if the calls, in the early 1990s, for the breaking down of inherited barriers within LIS had been implemented. The report of the Task Team on Library and Information Services of the Centre for Education Policy Development (CEPD), for example, recommended that school and public libraries be placed within one ministry, namely the Ministry of Education, and outlined a framework for an integrated public and school library system within the Ministry (Centre for Educational Policy Development 1994).

1. Genevieve Hart is a Professor in the Department of Library and Information Science, University of the Western Cape, South Africa.

2. Mary Nassimbeni is Emeritus Associate Professor in the Library and Information Studies Centre, University of Cape Town, South Africa.

3. This figure is taken from Equal Education. 2010: 21

4. According to the Southern and East African Consortium for Monitoring Educational Quality (SAQMEC), school library provision deteriorated in the period 2000-2007 by 5 points (Moloi and Chetty 2010) 
The neglect of libraries by the national Department of Education since the 1990s throws doubt on the wisdom of the CEPD's recommendation. Nonetheless, in this article, we argue that it is time to reconsider the existing configurations, suggesting that they do not meet the needs of the largest segment of the South African population, its children and youth; and therefore that the whole system is weakened. Ecosystems thinking suggests that many of the problems facing South African LIS, which are documented in the conference and journal literature, might emanate from the lack of access to libraries and information literacy education in schools. Thus, from the late 1990s, community librarians have been reporting the challenges of the huge increases in numbers of school learners from under-resourced schools (Nkosi 2000: 303; Hart 2004). They come in search of materials for their school assignments; but, in the absence of libraries in their schools, they do not know how to set about finding and using the information they need. Another example is the strong thread of comment on the under-preparedness of South African university entrants for higher education (for example De Jager \& Nassimbeni 2005; Hart \& Davids 2010). Academic librarians have to step in to teach the basic information skills that might be expected to have been learned at school. Information literacy is, moreover, not only a requirement of higher education. After all, only $15 \%$ of Grade 12 students gain university places and $50 \%$ of these drop out before graduation (Bloch 2009: 86). South Africa's aspirations to join the ranks of the global knowledge economies surely rely on information literacy among its school-leavers and future workforce - as do its aspirations for a vibrant democracy.

This article first explores the potential of ecosystems thinking in analysing the pressing issues confronting South African LIS and the planning for their future. It then focuses on the reading and information challenges facing South African youth and examines how the two subsystems directly serving youth, school and public libraries, are meeting these challenges. While the aim is to explore some encouraging evidence of adaptations on the ground, the article argues, however, that more than ad hoc adjustments and compromises are required if the country is to build a healthy and sustainable LIS ecosystem.

\section{Ecosystems and LIS}

There is consensus that socio-economic development in South Africa demands collaboration between the public and private sector - and collaboration among the various spheres and agencies of government. Inter-sectoral cooperation, or what ecosystems thinking might label "mutualism", is one of the principles of the South African Constitution in its statement, "All spheres of government and organs of state within each sphere must cooperate with one another in mutual trust and good faith by coordinating their actions and legislation with one another (South Africa. Constitution 1996: 21). Thus, in identifying unemployment and poor quality of education for most black children as the two most urgent issues facing the country, the National Planning Commission recommends "community involvement, better public service delivery, and a higher degree of social cohesion that promotes cooperation between all sectors to support economic growth and job creation" (2011: 16).

There is also growing acknowledgement across all sectors that sustainable development depends on education. Social grants and other government interventions are necessary ways to share the existing pool of resources more fairly; but education is what will expand the pool. Deputy Minister Joe Phaahla's statement on the educational mission of LIS during the Budget Vote in May 2012, therefore, is a timely reminder to librarians: "The role of libraries in educating our youth remains a priority. A reading nation is an educated nation who can handle the challenges of the present and future" (Phaahla 2012). This vocabulary resonates with librarians who will recognise these injunctions from the professional and philosophical LIS literature. The most recent draft of the LIS Transformation Charter, for example, while putting a focus on the needs of young people, promotes the educational mission of LIS and their role in social cohesion. It suggests that seamless or "borderless" services across a coordinated whole are required to meet the pressing information and developmental needs of all South Africans (The Library and Information Services (LIS) Transformation Charter 2009).

The relationships and synergy implicit in the concept of ecosystem suggest a perspective that locates school and public libraries in a system capable of meeting the needs of their users by taking account of the sector as a whole. The conceptualisation of an information ecology by Nardi and O'Day (1999) suggests the aptness of the metaphor of an ecosystem for LIS in South Africa:

- Strong inter-relationships and dependencies

- Continuous co-evolution

- Change is systemic

- Niches for many different roles and functions: complementarity in a healthy system

- Diversity.

Their description of factors in the environment and their relationships helps us to imagine our environment as an ecosystem. As Nardi and O’Day (1999) write:

A natural environment offers many toeholds for life of various forms. With tenacity and vigor, species migrate and change to fill the available niches. These adaptations lead in turn to further change, as the entire system adjusts to new constraints and possibilities.

There are changes in the environment - gradual or sudden - and LIS have to adapt to change or face extinction. So, the LIS profession needs to be aware of the changes/challenges affecting us - such as funding, governance, the Internet, 
mobile telephony, the digital economy, scholarly communication, and competition from other information agencies - so that we can manage them. The organisms must have the apparatus to detect the source and type of threat in order to adapt appropriately, or else suffer extinction. An example from the past lies in the demise of the resource centre movement which flourished in the years of struggle where information was at a premium, remaining the preserve of the privileged, while the masses were excluded from the flows of information for fear (that is, the government's fear) that they would harness it for their liberation. After 1994, with the establishment of a democratic state, foreign funding was directed towards the legitimately elected democratic government, with the consequence that many of the resource centres floundered and had to close (Ewing \& Guliwe 2008: 251).

\section{Challenges of South African youth}

The status of library services to children and youth is of particular concern for two reasons: the dominance of youth in South African demographics and the disproportionate socio-economic challenges young people face. The latest 2011 census reveals the median age across all main population groups to be 25 years, with the medians of the Black African and Coloured groups a few years younger (Statistics South Africa 2012: 21). South African children and youth are at disproportionate risk for a number of reasons: poverty, poor schooling, effects of HIV/AIDS on the stability of families, and abuse. Of the estimated population of 50 million in South Africa, $60 \%$ are below the poverty line of R550 per month; and $18 \%$ of children younger than 17 have lost either one or both parents (Statistics South Africa 2012: 68). It is estimated that between 95,000 and 125,000 children live in child-headed households (Statistics South Africa 2010).

The focus in a discussion paper from National Treasury in 2011 is the disproportionate socio-economic challenges faced by South African youth, defined as those between 18 and 30 years. The paper provides figures that show that:

- About $42 \%$ of young people under the age of 30 are unemployed compared with less than $17 \%$ of adults over 30 .

- Only one in eight working age adults under 25 years of age has a job compared with $40 \%$ in most emerging economies.

- $86 \%$ of unemployed young people do not have formal further or tertiary education.

The authors warn that unemployment is associated with "social problems such as poverty, crime, violence, a loss of morale, social degradation and political disengagement" (South Africa. National Treasury 2011: 9).

South African schooling must be included in this discussion of the challenges confronting South African young people. The South African government spends a relatively high six percent of its gross domestic product (GDP) on education, having inherited daunting backlogs (Equal Education 2011). The Minister of Basic Education has stated that it will take 30 years to build the necessary school infrastructure like classrooms, brick walls, and toilets - at a cost of six billion rands (Motshekga 2012). School attendance has grown to 99\% for children younger than 13 years and to $93 \%$ for those from 14 to 17 years (Statistics South Africa 2010). But only fifty-two of every 100 who start Grade 1 reach Grade 12 (Bloch 2009: 68).

The educationist Graeme Bloch calls the underachievement of South African schools a "national disaster" (2009: 58). The annual assessment scores for 2011 lend support to his claim. They reveal that at Grade 3 the national average for literacy was 35\% and for numeracy 28\%; at Grade 6 it was 28\% for languages and 30\% for mathematics (South Africa. Department of Basic Education 2011: 20). Performance varies across the various sectors of schooling: the third Southern and East African Consortium for Monitoring Educational Quality (SAQMEC III) survey of school quality reports "disappointingly low achievement results of learners from rural and low socio-economic sectors" (Moloi \& Chetty 2010: 88). Although it is no longer meaningful to talk of "white" schools, it seems that the dice are still loaded against black children in what Bloch calls the schools of the "second economy" (2009: 59).

The statistics in this section surely must raise questions among South Africa librarians as to where young people turn to for information - vital "everyday life" information as well as that needed for their formal education. Stilwell's survey of South African research in information behaviour (2010) indicates a dearth of research in young people's information needs. Almost all of her references are to studies of adults or university students. The studies of young people's needs that do exist reveal dire gaps in service. In her doctoral study of information services to young people in the Eastern Cape, Nkosi quoted a librarian talking of children crying to be admitted to an over-crowded library (2000: 303). A study by an Ethekweni community library showed the need for information on topics like anger, grieving, stigma, gangs, date rape, sexuality, family violence, and drugs (Stillwell \& Bell 2003). Among the respondents older than 13 years, "information for school projects" was the most frequently cited wish. Rubushe's Masters degree study in 2000 of 111 Eastern Cape young people found widespread ignorance of HIV/Aids, sex, drugs and alcohol. Rubushe's project, reportedly, went beyond the mere listing of gaps in information. According to Stilwell and Bell (2003), her respondents were found to be in urgent need of skills in decision making and problem solving. Information is more than a commodity - which, if provided and "taken", will solve problems. Information demands cognitive processing into personal meaning and knowledge. The implication for librarians who work with young people is that their work entails more than the provision of facts or resources - rather it implies educating young people in information literacy. 


\section{South African LIS services to children and youth}

The above discussion suggests that South African librarians, across all sectors, need to mobilise to address weaknesses in the delivery of library and information services to children and youth. The starting point can be simply expressed: "What are we doing wrong, or neglecting to do, that can explain the intractability of the problem?"

In this section, we examine the subsystems of school and community libraries in the light of the above description of the challenges facing young South Africans. This will lead to an exploration of some alternative approaches, encountered on the ground, that demonstrate the value of the ecosystems approach.

\subsection{School libraries}

A large body of international research provides evidence of the contribution of school libraries to literacy, information literacy and to overall school quality - with organisations like the International Association of School Librarianship collating references to the various studies (www.IASL.org). This research has documented their impact on academic performance, as well as on social cohesion and school well-being.

The chapter devoted to school libraries in the sixth draft of The LIS Transformation Charter, commissioned by the National Council of Library and Information Services (NCLIS) (The LIS Transformation Charter 2009), provides a comprehensive overview of South African school librarianship. It identifies the key challenges as:

- Fewer than $10 \%$ of schools have functioning libraries - that is, libraries with annual materials budgets and dedicated staff. On the whole, these few are the historically advantaged, suburban schools, which are able to supplement their government budgets by levying fees to pay for "extras". The SAQMEC III report from the Department of Basic Education reveals a "disconcerting" (Moloi \& Chetty 2010: 30) trend in post-apartheid schooling in its admission that, between 2001 and 2007, school libraries had decreased in three provinces, the Eastern Cape, Kwazulu-Natal and Limpopo (all provinces with very low numbers to begin with).

- There is no national school library policy. The national Department of Basic Education (DBE) has recently issued a new document, School Library Guidelines (South Africa. Department of Basic Education 2012). The Department reportedly is wary of committing to formal policy without the funding to implement it. It has to be said that the Guidelines have had a lukewarm response with doubts over their likely impact.

- The lack of provision of school librarian posts. National policy is crucial here since the provisioning of staff is outside the provincial mandate. The schools with school librarians are those able to appoint "extra" staff beyond national norms on so-called School Governing Body contracts. International research shows that professionally qualified librarians have a critical impact on academic performance - with their collaborative information literacy programmes identified as their most important contribution (Lance 2012; School libraries work! 2008).

- The lack of a unit in the national education department to take on a leadership role.

- The weak capacity of the provincial education departments' school library support services.

A relatively new player in the school library subsystem is the non-governmental organisation (NGO) Equal Education, which has recognised the role of libraries in quality education and in redressing past inequalities. Its campaign "One School, One Library, One Librarian" has put pressure on the South African government to include libraries as part of schools' legal infrastructural entitlement (Equal Education 2010). The NGO has set up libraries in disadvantaged schools in Cape Town; however, the reality is that those without dedicated staff will remain closed for most of the school day. Libraries are more than collections of books. As Budd points out, "Library as place doesn't simply appear .... Librarians make the place; they take space and shape it, imbue it with texts, add their professional expertise, and open it to people" (Budd 2008: 236).

Despite the years of advocacy from librarians and, more recently, from Equal Education, the stark reality is that the South African school library sub-system is close to extinction. The reluctance of the national education authorities to take a leadership role in reviving it is clear. The Minister of Education is on record as saying that it will take thirty years to build adequate school infrastructure, including libraries (Motshekga 2012). This kind of statement raises the question of how learners and teachers are expected to cope with the kind of resource-based learning demanded by the curriculum and by the $21^{\text {st }}$ century global economy. As already mentioned, there is anecdotal and research evidence that the lack of libraries and resources in their schools has meant that they turn to public libraries. This then must raise another question: How have public libraries responded?

\subsection{Public libraries}

The KPMG report in 2007 for the Department of Arts and Culture (DAC) on the status quo of public libraries in South Africa acted as the framework for the renewal of public library services after years of neglect and decline (South Africa. Department of Arts and Culture 2007). It preceded the financial investment of R1 billion which came into effect in April 2007. Another large grant of close to R1, 8 billion was announced in 2012 (Xaba 2012).

The purpose of the funding from the Department of Arts and Culture (Community Library Conditional Grants) is "to transform urban and rural community library infrastructure, facilities and services (primarily targeting previously disadvantaged communities) through a recapitalised programme at provincial level in support of local government" (Kekana 2011). Since their inception, the Conditional Grants have been used as follows (National Library of South Africa 2012) to improve and enhance to provision of public library services: 
- Thirty-four new libraries have been built

- 229 libraries have been upgraded

- 1,575 staff members have been appointed

- Internet access has been improved in all provinces

- Reading facilities for the visually impaired have been rolled out in eleven community libraries, while six are in planning stages.

Although the grant has breathed new energy into the sector, public librarians' reports at annual conferences indicate that it stills faces daunting challenges such as:

- The insecure status of public libraries in their local authorities

- A general lack of appreciation of the value of public LIS among the general populace - as perhaps evidenced in the destruction of several public libraries in so-called service delivery protests in recent years

- A continuing shortage of libraries in rural areas - specifically in the former so-called apartheid homelands, which, despite being labelled "rural", are densely populated and still have the highest levels of poverty, unemployment and related social problems

- Inadequate human resources - in terms of numbers and professionalism. The conditional grants have provided new staff members; but they are largely on three-year contracts and there is concern over their sustainability.

By definition, public libraries serve all sectors of their communities, but the KPMG survey provided evidence of the dominance of their work in early-childhood development and the support of school learners. It revealed a strong focus on work with children: children's programmes were the most common activity with $80 \%$ of all public libraries offering these programmes (South Africa. Department of Arts and Culture 2007: 11). The study, moreover, concluded that the public library was performing the role of a school library (2007: 49).

The DAC grant funded, as well, the LIS Transformation Charter, which suggests that a more pronounced developmental and educational vision might enhance libraries' visibility and status in society (The LIS Transformation Charter 2009: 19). It acknowledges the pressing reading and information needs of South African young people and, as already mentioned, devotes a long chapter to the plight of school libraries. The Transformation Charter returns repeatedly to the theme of purposive and targeted planning, and the importance of coherence, coordination and collaboration in order to achieve a "borderless" system of libraries. It thus recommends closer cooperation between public libraries and schools.

\section{Models of collaboration}

In pursuit of models possibly compatible with our interest in LIS ecosystems, in September 2012 we visited two newlybuilt libraries, a public library in a township in Cape Town and a dual-use school community library, which acts both as a school library and a community library. The public library is in a sprawling township where hardly any schools have libraries; and the dual-use library is set in a school in a farming community outside Cape Town where the nearest public libraries are in towns some kilometres distant.

\subsection{The public library}

The purpose of our visit and interviews in the public library was to assess the extent to which its planning and practice incorporated purposeful interaction with neighbouring schools. The site was a new community library in a township with an estimated 200,000 families in an area of six square kilometres - one of the highest population densities in South Africa. The library, opened a few years ago, serves an estimated population of 40,000 , four schools and fifty preschools. In their planning they identified early childhood development as the focus of their programming and so have through intensive marketing successfully developed a relationship with all the pre-primary schools in the area. These schools visit the library on a regular basis where the programmes are offered in a specially designed area equipped with furniture, toys, games and books - a pioneering innovation in public librarianship in South Africa.

Their marketing to the three primary schools and the one high school in the neighbourhood has not been successful with only one primary school taking up the offer of participating in their regular schools programme. Interestingly, the sole positive response came from the school that has a small library with a librarian. One of the reasons advanced for the schools' inertia is the burden of arranging indemnity forms for the learners - a weak reason, we were told, as it is possible to arrange a single collective indemnity form for the whole group. Reported experience from the many librarians who have attempted fruitlessly to systematise relationships with neighbouring schools blames the situation on the lack of support by educational authorities. This is a plausible reason as there is overwhelming evidence that the majority of school teachers have had limited exposure in their training and daily experience of the value of the library in supporting reading literacy and the curriculum. They therefore need an incentive or a directive to disrupt their teaching practice to avail themselves of the opportunities offered by the public library.

Notwithstanding the poor level of cooperation from the schools in their catchment area, many learners do frequent the library where they get help with their assignments and where they have access to computers that are connected to the Internet. Since the local teachers do not liaise with the library about the projects, learners come to school with poorly understood topics for investigation requiring great ingenuity form the librarians to interpret the requirement of the 
assignments. One learner was sent to the library with the request for a book that "will help me develop myself", an instance of vagueness and poorly recognised concept of useful advice that is common.

The library reports that $80 \%$ of their users are learners, and that in July 2012 they issued 6,610 items and that their current footfall is 15,000 to 20,000 people a month. In the absence of formal relationships with the schools, they will continue to rely on word of mouth and so continue to offer the homework support to the learners who attend the library voluntarily to seek assistance with their studies. The library is making a significant contribution to early childhood development in keeping with its founding mission. While its work with the learners and youth is commendable, it is selfevident that a coordinated approach with teachers would achieve more with the same degree of effort. Working directly with teachers as they plan and implement their class assignments would extend the reach of the library; and formal programmes would introduce groups, rather than individuals, to the library and orientate them to the services on offer.

This case is, arguably, fairly typical of public libraries throughout South Africa. It is probably true that it is doing the work of a school library, although, as yet, it has not documented its impact on its surrounding schools. Another unanswered question is what proportion of the total number of school learners in the area use its services.

\subsection{The dual-use school community library}

The public librarians' comments on the problems in establishing formal programmes with its neighbouring schools echo those of public library staff in other environments (Maepa \& Mhinga, 2003; Hart 2006). Typically, a public library serves a number of schools and its services to school users are just one part of its work. It might therefore struggle to build the close relationships with teachers that good school libraries depend on.

Earlier, mention was made of the DBE School LIS Guidelines which list possible school library options. One of the options offered is a school community library - a "centralised library situated in the school which is also used by members of the community" (South Africa. Department of Basic Education 2012: 15). Clearly this model, which cuts across traditional barriers, is of interest in an exploration of the LIS ecosystem metaphor. There are indeed examples of dual use libraries scattered throughout the country. One of the authors has, before, written up a case study of the "tricky business" of shared use in six schools in a remote rural area in a more northern province, which lay the ground for this analysis of the dual-use library in the Western Cape (Hart 2011). The international professional and research literature provides a set of guidelines for dual use LIS, such as:

- user communities of a manageable size $(10,000$ is the number often cited)

- formal planning involving all stakeholders

- visible and convenient location

- a separate area for adults

- connections to a larger network

- one highly motivated professional in charge, preferably qualified in both education and librarianship

- a shared learner-centred philosophy of education.

Hart's earlier case study (2011) concluded that a rigorous application of all the guidelines in the South African context would be impossible and, indeed, unnecessary. The case study libraries were innovative attempts to meet the needs of schools and the community. Their key weakness was found to be the lack of standing in their schools of the library staff (employees of the provincial public library service). Teachers saw them as "public library people" and did not consult with them in their teaching or curricular planning. The role of the so-called teacher-librarians, who, on paper, were responsible for the libraries, was sketchy. They were full-time teachers who occasionally "popped in" to the libraries.

The two fundamental requirements for success of dual use LIS in the South African context that emerged from the earlier case study are:

- Cost saving cannot be the sole motivator. The dual use LIS must be both a good school library and a good community library. Hart's earlier case study sites were found to be mostly used by learners from the schools in the surrounding area and unemployed youth. Given the fact that the public library in that province alone is providing the staff (on annual contracts) and the library stock, the low use by adults in the surrounding communities might raise concerns over the libraries' sustainability.

- Formal agreements, involving all stakeholders, including those in the user communities, are essential to spell out responsibilities, including those relating to children's security. For ongoing functioning and sustainability, the partnerships must be real, with each partner having something the other needs. The contribution of each might not be equally visible. For example, in the earlier case study (Hart 2011), the provincial Education Department and the schools had provided the sites needed by the provincial public library to extend its reach in rural areas but they were now contributing very little in the way of tangible resources. The staff, equipment, and materials were coming from the public library. However, the curricular and pedagogical knowledge of the Education Department's regional school library official was invaluable in the ongoing training and support of the library staff, whose public library background had not prepared them for their work with school learners.

From the school library perspective, the dual-use library in the Western Cape is of particular interest because it is a rare example of a fully functional library, managed by a qualified school librarian, in a disadvantaged school. It is, 
moreover, a library that meets established and growing community needs, having replaced an existing, but inadequate, public library service. Although our interviews and the follow up phone calls and emails cannot be described as an indepth case study, they did provide insights into the ecosystem concepts of mutualism and co-evolution. The preamble to the Co-operative Agreement in Respect of Library Services, signed by the three partners - the Department of Cultural Affairs \& Sport of the Provincial Government, the local municipality, and the School Governing Body - reveals how the interests of each are served. The agreement, to run from 2011 until 2014, comes from recognition by the province and municipality that the community (comprising about 9,000 inhabitants) is in need of a library. A depot library operating from a caravan for a few hours a week was in place before. The school agrees to allow public access to the newly built library, designed to provide separate access points for school children and community members. In return it gets provincial and municipal library materials and equipment - and staffing that keeps the library open every afternoon and on Saturday mornings.

The agreement makes no mention of the possibly key factor in the success of the model - the presence of a qualified teacher-librarian. The interviews on site soon revealed that she is accepted as the library manager and, in that capacity, attends the regular municipal library meetings. She is, however, on the teaching staff of the school as a life orientation teacher and, unlike the nominal teacher- librarians in Hart's earlier case study sites, is based in the library for much of the school day. On being asked how he has managed to find room for a librarian on his staff quota, the principal claims that it is a matter of "planning and attitude".

The point here is that the school librarian has access to the teachers' staff room and their planning meetings. She spends much of her day working collaboratively with teachers and their classes in the library. The principal is convinced that her work benefits the school's academic performance; literacy scores are improving and some of its Grade 7 children are being accepted into what he calls the "top" schools in the nearby towns.

In keeping with the international research evidence of the crucial role of principals in school librarianship (for example Henri, Hay \& Oberg 2002; Lance 2012), the principal is clearly the driving force behind the dual use project. He reported that he had been trying to bring the concept of a "community school" to life for several years but without much success. Then, after coming across an article on a shared library in Sweden, he realised that a library might serve both his interests as an educator and his desire to play a part in the socio-economic development of the surrounding disadvantaged community. He consulted with key officials in the provincial library and education departments to put flesh on his idea and built a widely representative work-team in order to realise his vision.

The benefits of the school being a primary school, in terms of the principal's developmental vision and public library mission, were demonstrated in the course of our visit. Several mothers of small children were arriving to take them home and came into the library, which is close to the school entrance. It was encouraging to see how the public library assistant took the opportunity to engage with them and help them choose books to take home for family reading. We witnessed also the use of the library by students in other schools. The school bus stop is just outside the school and, as they come back from the high school in a neighbouring town, they use the library for their school work.

\section{Conclusions}

Our purpose in this article has been to explore the potential of ecosystems thinking to break down the barriers that we suggest are hindering the social and educational mission of South African LIS of all kinds. Given the pressing educational and information needs of South African youth and the huge backlogs in school infrastructure, which will take years to address, we suggest that it is time to rethink our traditional library configurations. We have described two libraries as examples of how South African libraries are transcending their conventional borders to meet the needs of their communities:

- The public library, in collaboration with NGOs, plays a crucial role in early childhood development and is surely contributing to the school readiness of the young children it serves. It is deliberately stepping in to serve the needs of school learners in the vicinity, where there are no school libraries. However, as yet, its efforts to build more formal school programmes are hindered by a seeming lack of appreciation of their potential role among teachers in the surrounding schools.

- The school/community library is the outcome of teamwork by a wide range of stakeholders. Its teacher-librarian makes sure that her teaching is embedded in the school's day-to-day programmes; and in the afternoon it serves a number of other schools and the surrounding rural community.

Both libraries might illustrate the possibilities of an "information ecology" (Nardi \& O'Day (1999), the attributes of which were described earlier. Their success depends on the interrelationships among a wide range of players. They are adapting and evolving their services to meet the needs of their diverse user communities.

Our investigation has shown that public librarians recognise the educational crisis and the severe challenges faced by South African youth; it reveals a willingness to participate in solutions. Their attempts, however, to insert themselves into educational processes do not attract support from teachers in an educational system where boundaries are not easily transgressed. The resultant ad hoc and reactive approaches to intervening in the educational crisis reflect a weakly realised and implicit sense of mutualism as a means of more effective service delivery.

Throughout South Africa, there are scattered instances of successful collaboration which can provide the scaffolding for new configurations. These might range from formal agreements with schools for regular programmes of homework 
and information literacy support through scheduled visits to the establishment of joint use libraries. The risks of "one-sizefits- all" thinking are apparent. Different areas and communities will require different configurations, given geographical variations in resource provision, notably the extremes between rural and urban areas, particularly in former homelands.

The process should begin with an explicit acceptance that the response needs to be planned and purposeful. We thus support the call made at the 2012 conference of the Library and Information Association of South Africa for a colloquium to start a conversation that will move us towards a systematic, structured and sustainable LIS specifically designed to meet the needs of our children and youth for a future they deserve.

Acknowledgement: This paper is based on a presentation at the $14^{\text {th }}$ LIASA Annual Conference, Durban, October 2012.

\section{References}

Bloch, G. 2009. The toxic mix: what's wrong with South Africa's schools and how to fix it. Cape Town: Tafelberg.

Budd, J. 2008. Self-examination: the present and the future of librarianship. Westport, CT: Libraries Unlimited.

Centre for Education Policy Development. 1994. Implementation plan for education and training. Interim report of the Library and Information Services (LIS) Task Team. Johannesburg: CEPD. Unpublished report.

Davenport, T. H. and Prusak, L. 1997. Information ecology: mastering the information and knowledge environment. New York: Oxford University Press.

De Jager, K. \& Nassimbeni, M. 2005. Information literacy and quality assurance in South African higher education institutions. Libri, 55: 228-237

Equal Education. 2011. Equal Education briefing document for Portfolio Committee on basic education. Department of Basic Education annual performance 2010/2011. [Online].

http://www.equaleducation.org.za/sites/default/files/Briefing_Note.

Equal Education. 2010. We can't afford not to: costing the provision of functional school libraries in South Africa. Cape Town: Equal Education. [Online].

http://www.equaleducation.org.za/sites/default/files/Equal\%20Education\%20Costing\%20Booklet.pdf (Accessed 27 September 2012).

Ewing, D. \& Guliwe, T. 2008. Foreign donor funding since 1994. In Giving and solidarity: resource flows for poverty alleviation and development. A. Habib \& B. Maharaj, Eds. Cape Town: HSRC Press. 241-280.

Hart, G. 2011. The "tricky business" of dual use school community libraries: a case study in rural South Africa. Libri, 61(3): 211-225.

Hart, G. 2006. Public librarians and information literacy education: views from Mpumalanga Province. South African journal of libraries and information science, 72(3): 172-184.

Hart, G. 2004. Public libraries in South Africa: agents or victims of educational change? South African journal of libraries and information science, 70(2): 110-121.

Hart, G \& Davids, M. 2010. Challenges for information literacy education at a university of technology. Innovation, 36: 2541.

Henri, J, Hay, L, \& Oberg, D. 2002. An international study on principal influence and information services in schools: synergy in themes and methods. School libraries worldwide, 8(1): 49-70.

Kekana, P. 2011. Presentation to Select Committee on Education and Recreation 16 February 2011. [Online]. http://www.pmg.org.za/report/20110216-departmetn-arts-culture-library-transformation-charter-community-libr (Accessed 27 September 2012).

Lance, K.C. 2012. How Pennsylvanian school libraries pay off: investments in student achievement and academic standards. [Online]. http://paschoollibraryproject.org/2012 (Accessed 12 January 2013).

The Library and Information Services (LIS) Transformation Charter. 2009. $6^{\text {th }}$ draft. Commissioned by the Department of Arts and Culture (DAC) and National Council for Library and Information services (NCLIS).

Maepa, E. \& Mhinga, R. 2003. Integrating a community library into the teaching and learning programme of local schools: experiences from Seshego Community Library, South Africa. In IASL reports 2003: school libraries breaking down barriers. Selected papers from the 32nd Annual Conference of the International Association of School Librarianship and the 7th International Forum on Research in School Librarianship, Durban, South Africa, 7-11 July 2003. S. Zinn, G. Hart \& E. Howe, Eds. Seattle: IASL: 270-279.

Moloi, M Q. \& Chetty, M. 2010. The SACMEQ III project in South Africa: a study of the conditions of schooling and the quality of education. South Africa country report. Paris: SACMEQ; Pretoria: Department of Basic Education.

Motshekga, A. 2012. Keynote address by the Minister of Basic Education, Mrs Angie Motshekga, MP, on the Mandela Day 2012 "94+ schools project" launch. South African Government Information. [Online]. http://www.info.gov.za/speech/DynamicAction?pageid=461\&sid=26580\&tid=64178 (Accessed 8 April 2012).

Nardi, B \& O'Day, V. 1999. Information ecologies: using technology with heart. [Online]. http://firstmonday.org/ojs/index.php/fm/article/view/672/582 (Accessed 27 September 2012).

National Library of South Africa. 2012. Community libraries conditional grant. Pamphlet compiled on behalf of the Department of Arts and Culture by the National Library of South Africa. Pretoria: National Library of South Africa.

National Planning Commission. 2011. National Development Plan: Vision 2030. Pretoria: National Planning Commission. [Online]. http://www.npconline.co.za/medialib/downloads/home/NPC\%20National\%20Development\%20Plan\%20Vision\%2 02030\%20-lo-res.pdf (Accessed 8 October 2012). 
Nkosi, L. P. N. 2000. Information provision to black youth in the Eastern Cape Province of South Africa. Unpublished DPhil thesis, University of Wales Aberystwyth.

Phaahla, J. 2012. Deputy Minister Dr Joe Phaahla's Budget Vote Speech 2012/2013, 7 May 2012. [Online]. http://www.archivalplatform.org/news/entry/deputy_minister/ (Accessed 27 September 2012).

Rubushe, B. 2000. An exploratory study of the information needs of secondary school students in Mdantsane Township, Eastern Cape. Masters in Information studies thesis. University of Natal.

School libraries work! Research Foundation paper. 2008. New York: Scholastic Library Publishing.

South Africa. 1996. The Constitution of the Republic of South Africa, Act 108 of 1996. Cape Town: Government Printer.

South Africa. Department of Arts and Culture. 2007. Report on the investigation into the development of public/community libraries in South Africa, compiled by KPMG Services. [Online]. http://www.dac.gov.za/projects/ncflis. (Accessed 28 January 2013).

South Africa. Department of Basic Education. 2011. Report on the annual national assessments of 2011. Pretoria: Department of Basic Education. [Online]. http://www.education.gov.za/LinkClick.aspx?fileticket=1U5igeVjiqg\%3D\&tabi. (Accessed 28 January 2013).

South Africa. Department of Basic Education. 2012. National guidelines for school library and information services. Pretoria: Department of Basic Education.

South Africa. National Treasury. 2011. Confronting youth unemployment: policy options for South Africa. National Treasury discussion paper. [Online]. http://www.treasury.gov.za/documents/national\%20budget/2011/Confronting\%20youth\%20unemployment\%20\%20Policy\%20options.pdf (Accessed 8 April 2012).

South African Yearbook. 2011/2012. 2012. [Online]. http://www.gcis.gov.za/sites/default/files/docs/resourcecentre/yearbook/2011/09_Arts\%20and\%20Culture.pdf (Accessed 27 September 2013).

Statistics South Africa. 2010. Social profile of South Africa, 2002-2009. Pretoria: Statistics South Africa. [Online]. http://www.statssa.gov.za/publications/Report-03-19-00/Report-03-19-002009.pdf (Accessed 8 April 2012).

Statistics South Africa. 2012. Census 2011. [Online]. http://www.statssa.gov.za/Census2011/Products.asp (Accessed 3 January 2013].

Stilwell, C. 2010. Research into information behaviour in the South African context: a preliminary exploration and bibliography: 1980 to date. Innovation, 40: 1-33.

Stilwell, C. \& Bell, F. 2003. Information needs of learners at Emzamweni High School, Inadi, South Africa: a preliminary report on an assessment linked to the CHESP community based learning model. In IASL reports 2003: school libraries breaking down barriers. Selected papers from the 32nd Annual Conference of the International Association of School Librarianship and the 7th International Forum on Research in School Librarianship, Durban, South Africa, 7-11 July 2003. S. Zinn, G. Hart \& E. Howe, Eds. Seattle: IASL. 332- 343.

Walter, S. 2008. The library as ecosystem. Library Journal, 133 (16). [Online]. http://www.libraryjournal.com/article/CA6598103.html (Accessed 10 September 2012).

Williamson, K. 2005. Ecological theory of human information behavior. In Theories of information behavior. K.E. Fisher, S. Erdelez, \& L. McKechnie, Eds. Medford: Information Today. 128-132.

Xaba, S. 2012. Presentation to the Select Committee on Appropriations: 05 June 2012. Community Library Services Grant. 